\title{
PRELIMINARY STUDY OF THE URANIUM POTENTIAL OF TERTIARY ROCKS IN THE CENTRAL SAN JUAN BASIN, NEW MEXICO
}

\author{
BENDIX FIELD ENGINEERING CORPORATION \\ Grand Junction Operations \\ Grand Junction, Colorado 81501
}

\section{Amores 1}

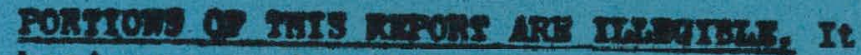
has boen roproduced f roe the bost avellablo copy to perntt the broadost poeanis atevis absists.

December 1977

ISSUED BY THE U.S. DEPARTMENT OF ENERGY GRAND JUNCTION OFFICE UNDER CONTRACT NO. E(05-1)-1664 


\section{DISCLAIMER}

This report was prepared as an account of work sponsored by an agency of the United States Government. Neither the United States Government nor any agency Thereof, nor any of their employees, makes any warranty, express or implied, or assumes any legal liability or responsibility for the accuracy, completeness, or usefulness of any information, apparatus, product, or process disclosed, or represents that its use would not infringe privately owned rights. Reference herein to any specific commercial product, process, or service by trade name, trademark, manufacturer, or otherwise does not necessarily constitute or imply its endorsement, recommendation, or favoring by the United States Government or any agency thereof. The views and opinions of authors expressed herein do not necessarily state or reflect those of the United States Government or any agency thereof. 


\section{DISCLAIMER}

Portions of this document may be illegible in electronic image products. Images are produced from the best available original document. 
This report was prepared as an account of work sponsored by the United States Government. Neither the United States nor the United States Department of Energy, nor any of their employees, nor any of their contractors, subcontractors, or their employees, makes any warranty, expressed or implied, or assumes any legal liability or responsibility for the accuracy, completeness or usefulness of any information, apparatus, product or process disclosed, or represents that its use would not infringe privately owned rights. 


\section{PRELIMINARY STUDY OF THE URANIUM POTENTIAL OF TERTIARY ROCKS IN THE CENTRAL SAN JUAN BASIN, NEW MEXICO}

H. P. Vizcaino and A. J. O'Neill



December 1977

PREPARED FOR THE U.S. ENERGY RESEARCH AND DEVELOPMENT ADMINISTRATION UNDER CONTRACT NO. E (05-1)-1664 
THIS PAGE

\section{WAS INTENTIONALLY LEFT BLANK}


CONTENTS

$\underline{\text { Page }}$

Summary . . . . . . . . . . . . . . . . . . . . . . 1

Introduction ........................... 2

Purpose . . . . . . . . . . . . . . . . . . . . . 2

Scope . . . . . . . . . . . . . . . . . . . . 2

Location . . . . . . . . . . . . . . . . . 2

Previous work ....................... 2

Geologic studies . . . . . . . . . . . . . 2

Exploration .................... 2

Geology . . . . . . . . . . . . . . . . . . . . . 5

Stratigraphy ...................... 5

Ojo Alamo Sandstone . . . . . . . . . . . . . 5

Nacimiento Formation ................ : 8

San Jose Formation . . . . . . . . . . . . 8

structure ........................ 9

Geologic history . . . . . . . . . . . . . . . . 9 9

Procedures . . . . . . . . . . . . . . . . . . . 11

T.i terature survey . . . . . . . . . . . . . . 11

Field . . . . ................. . . . . . . . . .

Subsurface . . . . . . . . . . . . . . . . . . 11

Laboratory . . . . . . . . . . . . . . . . . . 11

Evidence of uranium favorability . . . . . . . . . . . . . . 11

Known deposits....................... . . 11

Subsurface radiometric anomalies... . . . . . . . . . . 20

Favorability criteria present . . . . . . . . . . . 20

Source of uranium . . . . . . . . . . . . . 20 
CONTENTS (continued)

\section{Page}

Evidence of uranium favorability (continued)

Paleoenvironments ............... 20

Reductants .................. 22

Host rocks ...................... 22

Results ............................. 22

General ......................... 22

Subsurface investigations .................. 23

Lithofacies mapping . . . . . . . . . . . 23

Data from gamma-ray logs . . . . . . . . . . 23

Surface investigations . . . . . . . . . . . . . . . . . 24

Radiometric survey . . . . . . . . . . . 24

Known uranium occurrences ............... 24

Conclusions ......................... . . . . 24

Bibliography . . . . . . . . . . . . . . . . . 26 
CONTENTS (continued)

\author{
ILLUSTRATIONS
}

Page

Figure 1. Location of project area in relation to major tectonic elements of the San Juan Basin . . . . . . . . . . . 3

2. Locations of wells, uranium occurrences, and stratigraphic cross sections . . . . . . . . . 4

3. Generalized stratigraphic section of Tertiary rocks . . . 6

4. Geologic map of Tertiary rocks, central San Juan Basin. . 7

5. Structure contour map, base of the 0jo Alamo Sandstone. . 10

6. Subsurface radiometric map of Tertiary rocks . . . . . 12

7. Total sandstone isopach 0jo Alamo Sandstone ...... . 13

8. Sandstone-to-shale ratios with favorable subsurface trends, 0jo Alamo Sandstone . . . . . . . . . 14

9. Total sandstone isopach, Nacimiento Formation . . . . 15

10. Sandstone-to-shale ratios with favorable subsurface trends, Nacimiento Formation ........... 16

11. Total sandstone isopach, San Jose Formation . . . . . . 17

12. Sandstone-to-shale ratios with favorable subsurface trends, San Jose Formation . . . . . . . . . . 18

13. Early Tertiary paleogeographic map showing possible sediment source areas. . . . . . . . . . . 21

14. Uranium favorability map. . . . . . . . . . . 25

Plate 1. Stratigraphic cross section A-A', central San Juan Basin, New Mexico . . . . . . . . . In pocket

2. Stratigraphic cross section $B^{-} B^{\prime}$, central San Juan Basin, New Mexico ............. In pocket

3. Stratigraphic cross section ' $\mathrm{C}-\mathrm{C}^{\prime}$, central San Juan Basin, New Mexico............. In pocket

4. Stratigraphic cross section $D^{-} D^{\prime}$, central San Juan Basin, New Mexico . . . . . . . . . . In pocket 
CONTENTS (continued)

ILLUSTRATIONS (continued)

$\underline{\text { Page }}$

Table 1. Uranium occurrences in Tertiary rocks, San Juan Basin, New Mexico............... 19 
Three formations in the Tertiary of the San Juan Basin were investigated for their uranium favorability. They are the Ojo Alamo Sandstone, the Nacimiento Formation, and the San Jose Formation. The study comprised a literature survey and a basin analysis, which consisted of subsurface lithofacies, stratigraphic, and radiometric mapping. Field work in preparation for the subsurface analysis consisted of examination of outcrop and measured sections, surface radiometric traverses, and checking of reported surface radioactive anomalies.

Interpretation of subsurface mapping provided the primary basis for favorability assessment. The sandstone trends depicted in lithofacies maps, and stratigraphic cross sections reflect large channel complexes and major fluvial systems originating in favorable source areas.

Although surface radioactivity anomalies were found to be few, weak, and widespread, the San Juan Basin has abundant favorable host rocks. The subsurface anomalies, although weak, are widespread and sometimes persist throughout thickness intervals greater than $50 \mathrm{ft}$. Subsurface anomalies were mapped on a wide-spaced grid and are generalized.

On the basis of apparent source, lithology, differential permeability, content's of carbonaceous detritus, and geometry, the Nacimiento Formation and the basal facies of the San Jose Formation in the north-central basin have the greatest potential. The Ojo Alamo Sandstone is less favorable, and the Nacimiento Formation in the southern part of the basin and the upper San Jose Formation are the least favorable of the units studied. 


\section{INTRODUCTION}

\section{PURPOSE}

This report presents the results of a preliminary study of the uranium favorability of Tertiary rocks of the central San Juan Basin (as defined by Kelley, 1950) in New Mexico (Fig. 1). The investigation was conducted by Bendix Field Engineering Corporation (BFEC) for the Grand Junction Office of the U.S. Energy Research and Development Administration (ERDA).

\section{$\underline{\text { SCOPE }}$}

The 0jo Alamo Sandstone, the Nacimiento Formation, and the San Jose Formation were investigated for their uranium potential.. The evaluation was based primarily on subsurface analysis. The study was conducted trom December 1976 to March 1977.

\section{LOCATION}

The project area comprises about 4,800 sq mi in San Juan, Sandoval, and Rio Arriba Counties (Fig. 2). The region is covered by portions of the Aztec (NN 13-10) and Albuquerque (NI 13-1) $2^{\circ}$ quadrangles.

\section{FREVIOUS WORK}

Geulugle Studies

Fassett and Hinds (1971) compiled a geologic map of Cretaceous and Tertiary beds in the central San Juan Basin. Baltz (196/) studied the Upper Cretaceous and lower Tertiary beds in the southeastern basin, and Baltz and others (1966) studied the Cretaceous-Tertiary boundary in the westcrn basin.

The structural setting of the San Juan Basin and its relationship to uranium distribution in the basin was discussed by Kelley $(1950,1955)$. Peterson and others (1965) summarized the geologic history and economic genlngy of the hasin.

\section{Exploration}

Major deposits of uranium have been developed in the Grants Mineral Belt at the southern margin of the basin. Uranium has been produced from Jurassic and Cretaceous beds. The Jurassic Morrison Formation accounts for more than 95 percent of both production and known reserves. Elsewhere in the basin, however, only minor, widely scattered occurrences of uranium are known, and limited production is reported (Hilpert, 1969). 


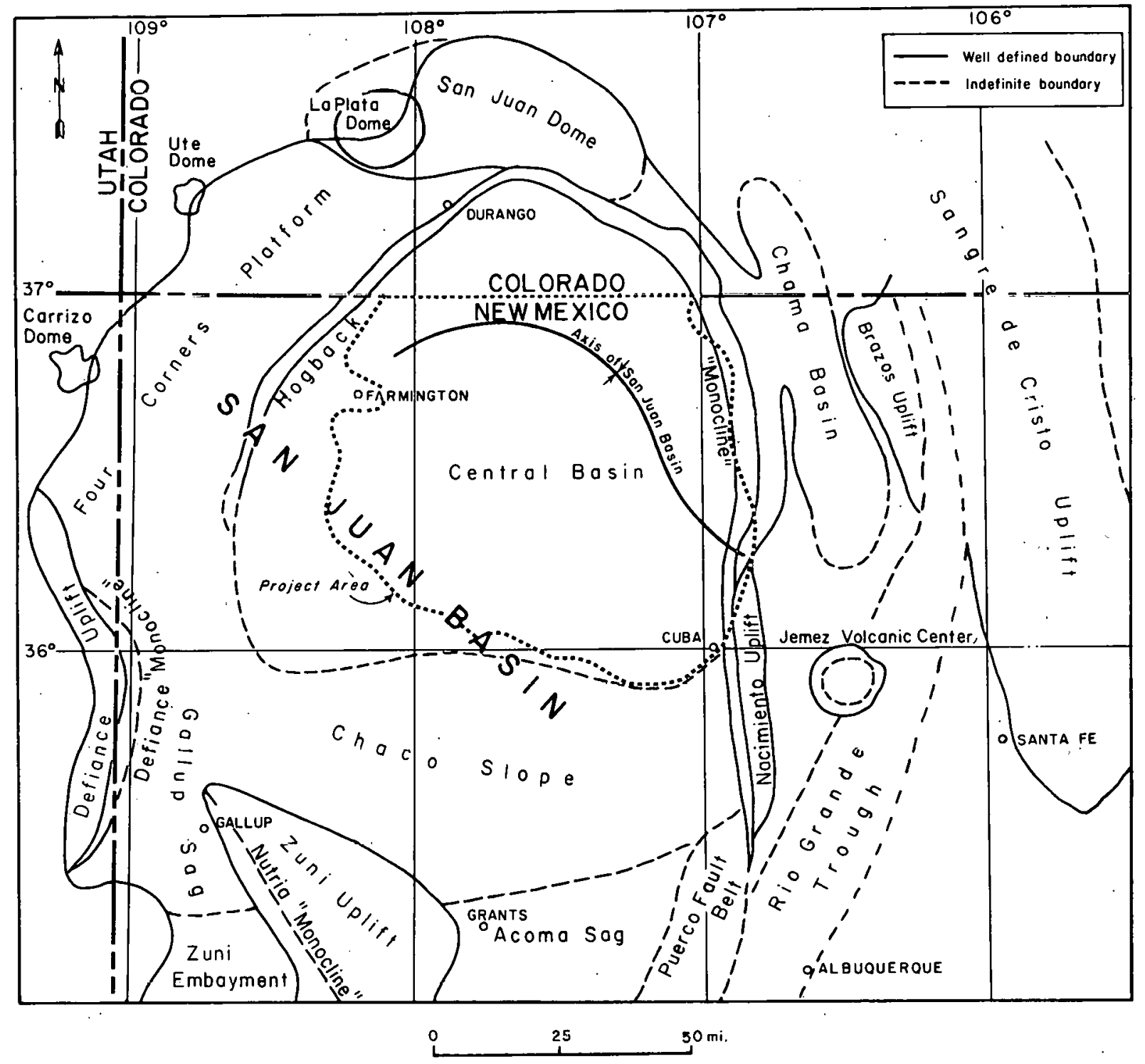

Figure 1. Location of projert area in relation to major tectonic elements of the San Juan Basin. (Modified from Baltz and Kelley, 1950). 




Figure 2. Locations of wells, uranium occurrences, and stratigraphil ciuss secliuns. 
Exploration for uranium in Tertiary rocks of the San Juan Basin has consisted mainly of U.S. Atomic Energy Commission aerial and ground reconnaissance surveys. These investigations were prompted mainly by the reported existence of several small, widely scattered uranium occurrences in Tertiary formations (Fig. 2). Outcrops of the Nacimiento and San Jose Formations were examined throughout a 900-sq-mi area in eastern San Juan Basin, from the New MexicoColorado boundary to the vicinity of Cuba (Chenoweth, 1957). The 0jo Alamo Sandstone was surveyed by Chenoweth and Stehle (1957) in the southeastern basin near Cuba and along the western margin near Farmington. They also investigated the San Jose in a 300-sq-mi area in northwestern Rio Arriba County. No radiometric anomalies in Tertiary rocks were detected. U.S. Geological Survey reconnaissance for uranium in the basin in 1951 and 1952 showed no uranium deposits of economic size, although a few localities near the base of the Wasatch (Cuba Mesa Member of the San Jose Formation) contained radioactive carbonaceous material (Bachman and others, 1952).

Extensive exploration for oil and gas has delineated major fields that are producing, mainly from Cretaceous rocks. The Cretaceous System also contains large reserves of coal, which have been strip mined to a limited extent. The Tertiary has some ground-water development. Ground-water hydrology of Tertiary rocks of the San Juan Basin has been summarized by Brimhal1 (1973) and Baltz and West (1967).

\section{GEOLOGY}

\section{$\underline{\text { STRATIGRAPHY }}$}

The Tertiary beds in the central San Juan Basin comprise the basal 0jo Alamo Sandstone, the Nacimiento Formation, and the San Jose Formation. They consist of thick, alternating units of sandstone and shale that extend from the surface to depths exceeding 3,500 ft near the axis of the basin. A columnar section (Fig. 3) summarizes the lighology, thickness, and contact relationships of the Tertiary formations.

\section{Ojo Alamo Sands tone}

The 0jo Alamo Sandstone (Fig. 4) is a conglomeratic sandstone that was deposited under fluvial conditions during early Paleocene time (Baltz and others, 1966). The 0jo Alamo varies in thickness, partly because of deep channeling at its base and partly due to extensive intertonguing with the overlying Nacimiento. Around the southern and southeastern rims of the basin, it is generally 70 to $110 \mathrm{ft}$ thick but thickens gradually both northward and westward. We11s in the north-central basin commonly penetrate $200 \mathrm{ft}$ of $0 \mathrm{jo} \mathrm{Alamo}$, and 200-ft-thick exposures have been measured along the bluffs of the San Juan River south of Farmington (Baltz and others, 1966).

The 0jo Alamo consists of buff, soft- to well-consolidated, medium- to coarse-grained sandstone, which commonly contains thin interbeds of olive-green Lu gray shale and sandy shale. The sand grains consist mainly of angular to subangular quartz, with accessory feldspar, rock fragments, and chert, which are commonly cemented with calcite or clay. Pebbles are scattered through the 


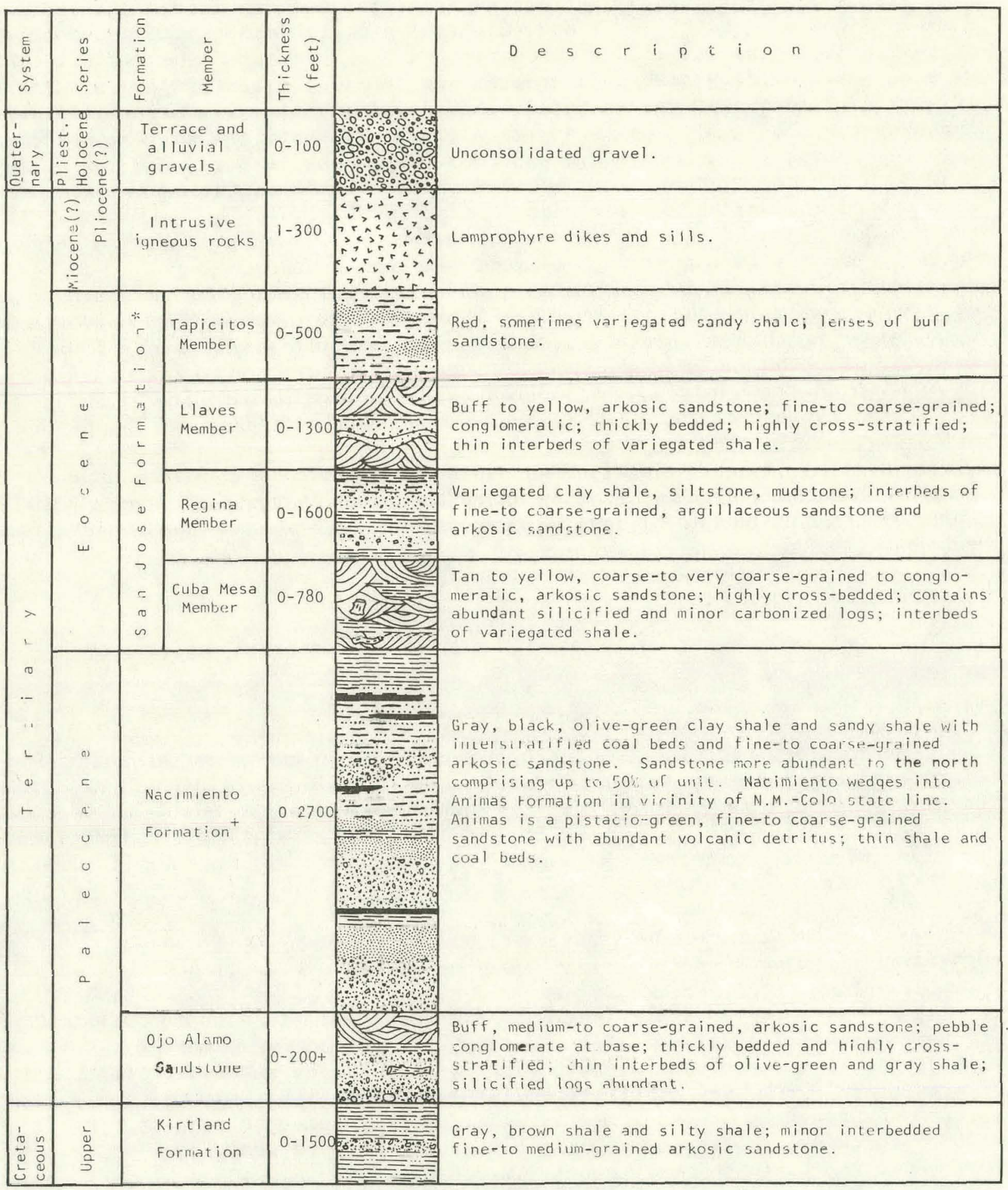

*Divided in southeastern part of basin by Baltz (1967)

tand cquivalenl parts of Animas formation

Figure 3. Generalized stratigraphic section of Tertiary rocks. 




Figure 4. Fenlngic map of Tertiary rocks, central San Juan Basin. 
sandstone at many places, and, 1ocally, the lowermost part of the formation is pebble conglomerate. Petrified logs are abundant throughout; only small amounts of carbonaceous material are found locally.

The 0jo Alamo rests, with slight angular unconformity, on the Upper Cretaceous Kirtland shale. In the northernmost part of the basin, the ojo Alamo interfingers with and wedges into the Animas Formation (Peterson and others, 1965). The Ojo Alamo grades upward into the Nacimiento Formation.

\section{Nacimiento Formation}

The Nacimiento Formation (Paleocene) is the name proposed by Simpson (1948) for a series of drab-colored mudstones, shales, and sandstones that are exposed throughout the southern and western parts of the basin (Fig. 4). Local irregularities in formation thicknesses are common around the basin rim; however, in the subsurface the Nacimiento thickens gradually from about $800 \mathrm{ft}$ in the south to approximately 2,000 $\mathrm{ft}$ in the north-central basin.

In the southern third of the basin, the Nacimiento consists mainly of gray to olive-green, red-banded shale and sandy shale interbedded with minor amounts of sandstone and, locally, with coal. In the central and northern parts of the basin, the formation contains a greater proportion of sandstone and, 1ocally, more than half of the unit is sandstone. The sandstones are fine to coarse grained to conglomeratic and range in composition from feldspathic to arkosic. They are lithologically similar to, but generally thinner than, those of the San Jose Formation.

The Nacimiento conformably overlies and intertongues extensively with the Ojo Alamo Sandstone (Baltz, 1967). Northward, near the New Mexico-Colorado state line, the Nacimiento grades into the upper part of the Animas Formation. The contact of the Nacimiento and overlying San Jose is one of angular and erosional unconformity, general1y characterized by channel scours filled with cuarse-grained, pebble-bearing sandstone of the San Jose Formation (Baltz, 1967).

\section{San Jose Formation}

The San Jose formation (early Eocene) [Simpson, 1948] includes the youngest Tertiary sedimentary rocks in the basin (Fig. 4). Baltz (1967) rnnrlided that the San Jose comprises four alternating sandstone-shale units in the southeastern part of the basin, which he formally defined, in ascending order: the Cuba Mesa, Kegina, Llaves, and Tapicitos Members. The members have not been formally exLellded vut of Baltz's study area, but Brimlı11's (1973) subsurface investigation confirmed that four mappable rock units exist elsewhere in the basin. Only the lower two, however, are present throughout most of the formation.

The thickness of the San Jose is markedly variable, a condition that resulted mainly from deep erosion rather than from original depositional patterns. The formation generally ranges from about 800 to $1,600 \mathrm{ft}$ in thickness; however, it thickens toward the east-central part of the basin to as much as $2,400 \mathrm{ft}$ thick (Baltz, 1967). 
The San Jose Formation is most completely preserved in the southeastern corner of the basin, where the four members are widely exposed. The most persistent and widespread unit in the San Jose is a basal conglomeratic sandstone facies interbedded with red, green, and gray shale. Termed the "Cuba Mesa Member" by Baltz (1967), the unit is mostly tan to yellow, cross bedded, quartzose to feldspathic sandstone that averages $300 \mathrm{ft}$ in thickness. It is coarse- to very coarse-grained and contains well-rounded pebbles and cobbles of quartzite, granite, chert, and a few volcanic rocks. Silicified wood is abundant, and carbonaceous material is found locally in small amounts.

Throughout most of its extent, the basal sandstone unit intertongues extensively with a thick (600-1,600 ft) overlying shale unit (Regina Member), which consists mostly of variegated shale with minor interbeds of fine- to coarse-grained, argillaceous sandstone and arkosic sandstone. The shale unit, in turn, interfingers with an overlying sandstone facies (Llaves Member), which is mainly restricted to the north-central and northeastern basin. It is lithologically similar to the basal sandstone unit, but is generally more thickly bedded and arkosic. Deep erosion and intertonguing relationships are responsible for a wide range in unit thickness; approximately $1,300 \mathrm{ft}$ is preserved at its type section north of Cuba. Locally overlying the Llaves Member is a red and sometimes variegated sandy shale (Tapicitos Member). It has been deeply eroded, and the thickest preserved section is about $500 \mathrm{ft}$.

\section{STRUCTURE}

The San Juan Basin is an asymmetric structural depression with steep dips on the north and east and with gentle dips on the south and west. Structural uplifts and platforms are prominent around the broadly downwarped central basin (Fig. 1), much of which is covered by early Tertiary or Late Cretaceous continental sediments. The structural features of the basin are complex on the eastern and northern margins, less complex on the south and west, and relatively undisturbed in the centrai basin (Fig. 5).

\section{GEOLOGIC HISTORY}

At the inception of Cenozoic time, the San Juan Basin was a trough probably not far above sea level and surrounded by newly formed mountains (Hilpert, 1969). Early Paleocene drainage (south-southeastward) and late Paleocene and early Eocene drainage (west-northwestward) deposited several thousand feet of lacustrine and fluvial sediments in the lower parts of the basin.

Late Tertiary epeirogenic uplift and volcanism caused general degradation of the basin. The erosional process continues at present. 


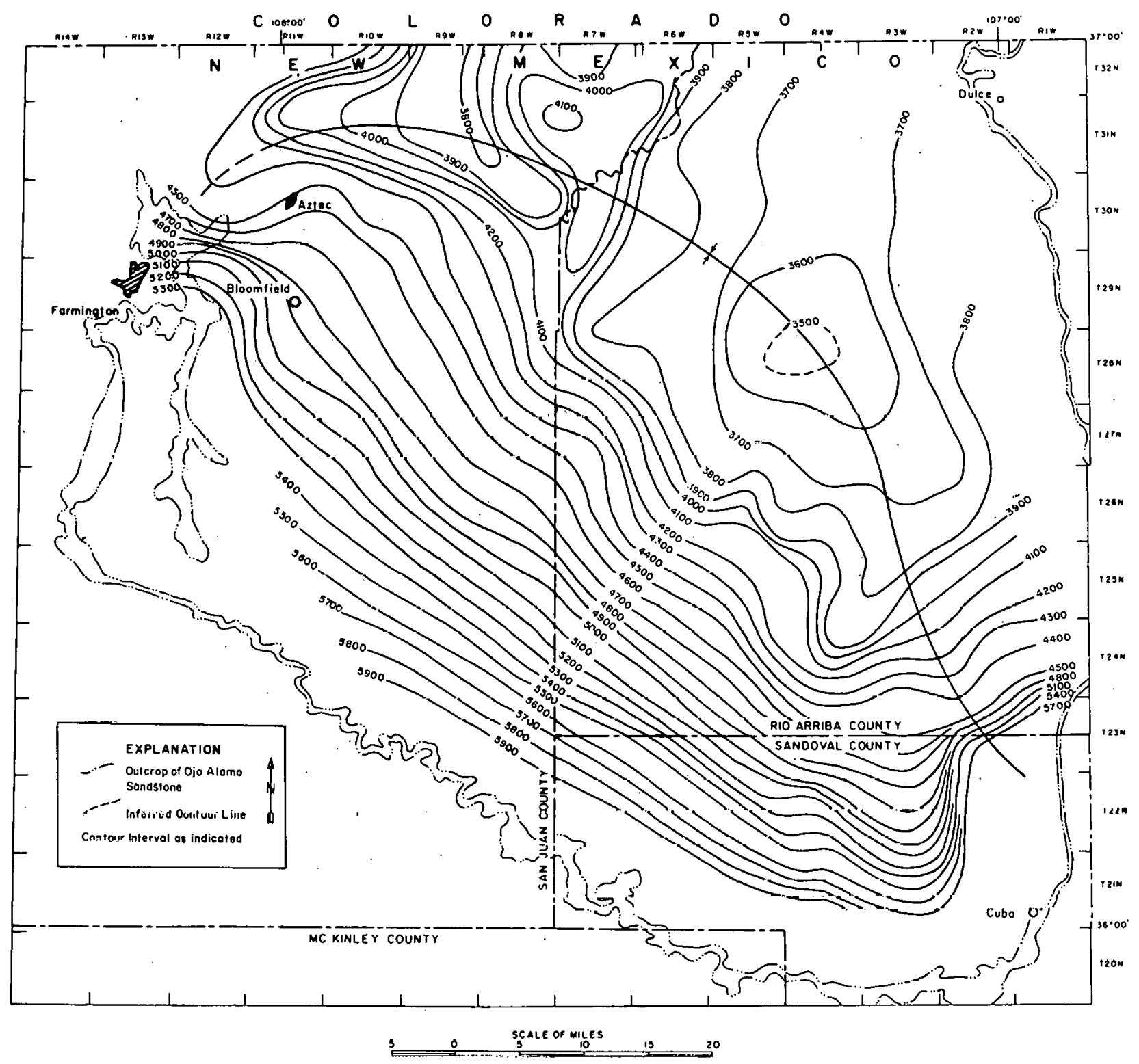

Figure 5. Structure contour map, base of the 0jo Alamo Sandstone. 


\title{
PROCEDURES
}

\section{LITERATURE SURVEY}

Published articles, reports, and maps were reviewed. Information about uranium occurrences in Tertiary rocks was derived mainly from U.S. Atomic Energy Commission open-file reports.

\section{$\underline{\text { FIELD }}$}

Outcrops of Tertiary rocks in the central San Juan Basin were examined, and published stratigraphic sections were studied. Reported uranium occurrences were located and examined (Fig. 2). Surface radiometric surveys were made with a Mt. Sopris SC-131 Scintillometer. (Use of a manufacturer's name does not constitute an endorsement.)

\section{$\underline{\text { SUBSURFACE }}$}

The subsurface study was based on the analysis of 130 electric logs (Fig. 2) and 600 gamma-ray logs of petroleum test wells in the central San Juan Basin (Fig. 6). Data from the electric logs provided the information for compiling lithofacies maps of each formation (Figs. 7-12) and stratigraphic profile sections (Pls. 1-4). Gamma-ray log data provided the information for radiometric mapping. Lithofacies maps include (1) net (total) sandstone and (2) sandstone-shale ratio for each formation. A structure-contour map on the base of the 0jo Alamo Sandstone was also prepared (Fig. 5). A study of Iithologic logs compiled by the American Stratigraphic Company (AMSTRAT) and an analysis of published subsurface studies provided the necessary control for the correlation of units.

\section{LABORATORY}

Reported uranium occurrences (Fig. 2) were not considered significantly anomalous (greater than $2 \mathrm{X}$ background) to justify systematic sampling and laboratory ana1.ysis.

\author{
EVIDENCE OF URANIUM FAVORABILITY
}

\section{KNOWN DEPOSITS}

Eleven uranium occurrences have been reported in the San Juan Băsin (Table 1): The occurrences examined during this study are weak, localized anomalies associated mainly with carbon trash and (or) black shales. There are no known uranium deposits in the Tertiary beds of the central San Juan Basin." 




Figure 6. Subsurface radiometric map of Tertiary rocks. 


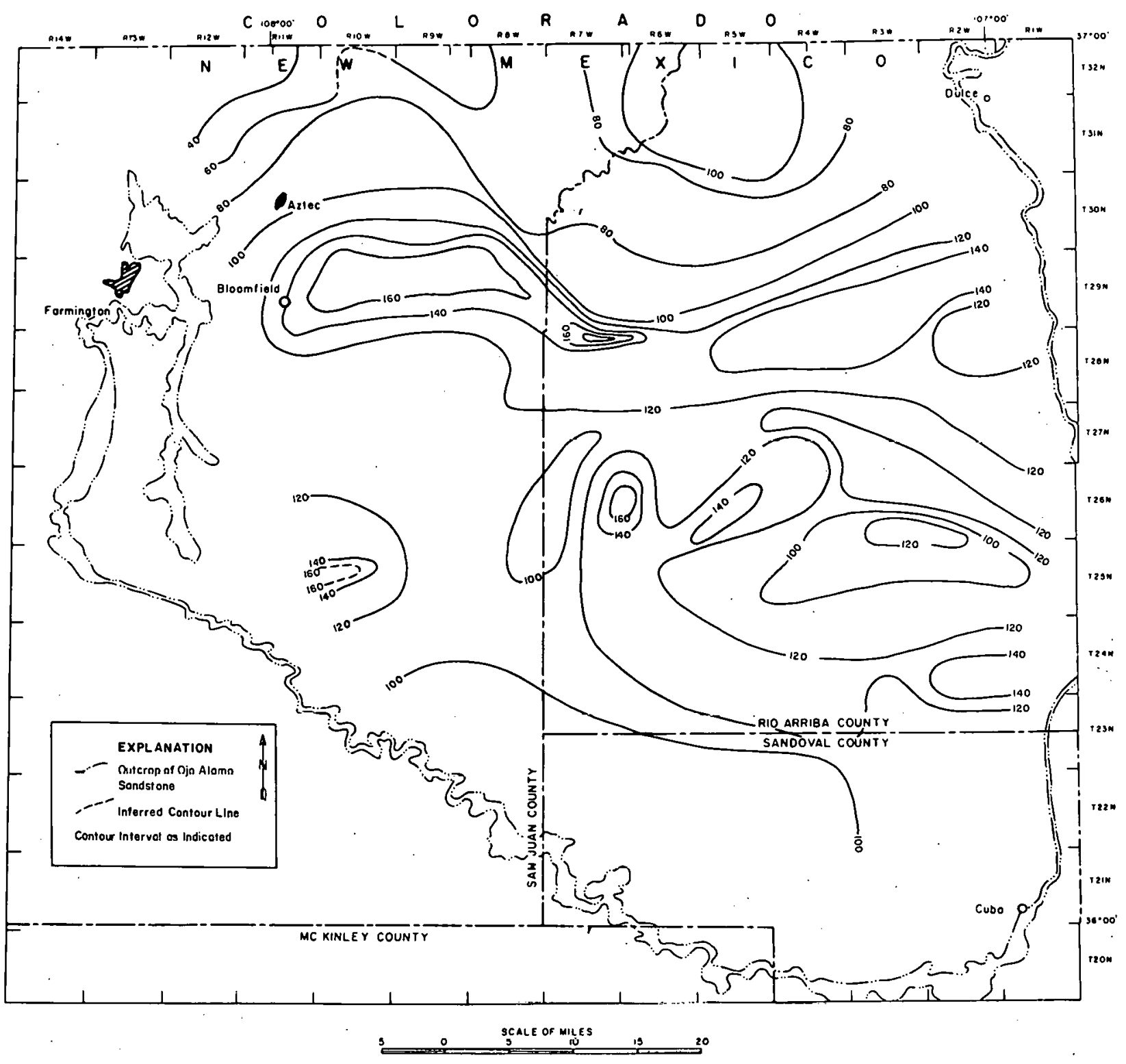

Figure 7. Total sandstone isopach 0jo Alamo Sandstone. 


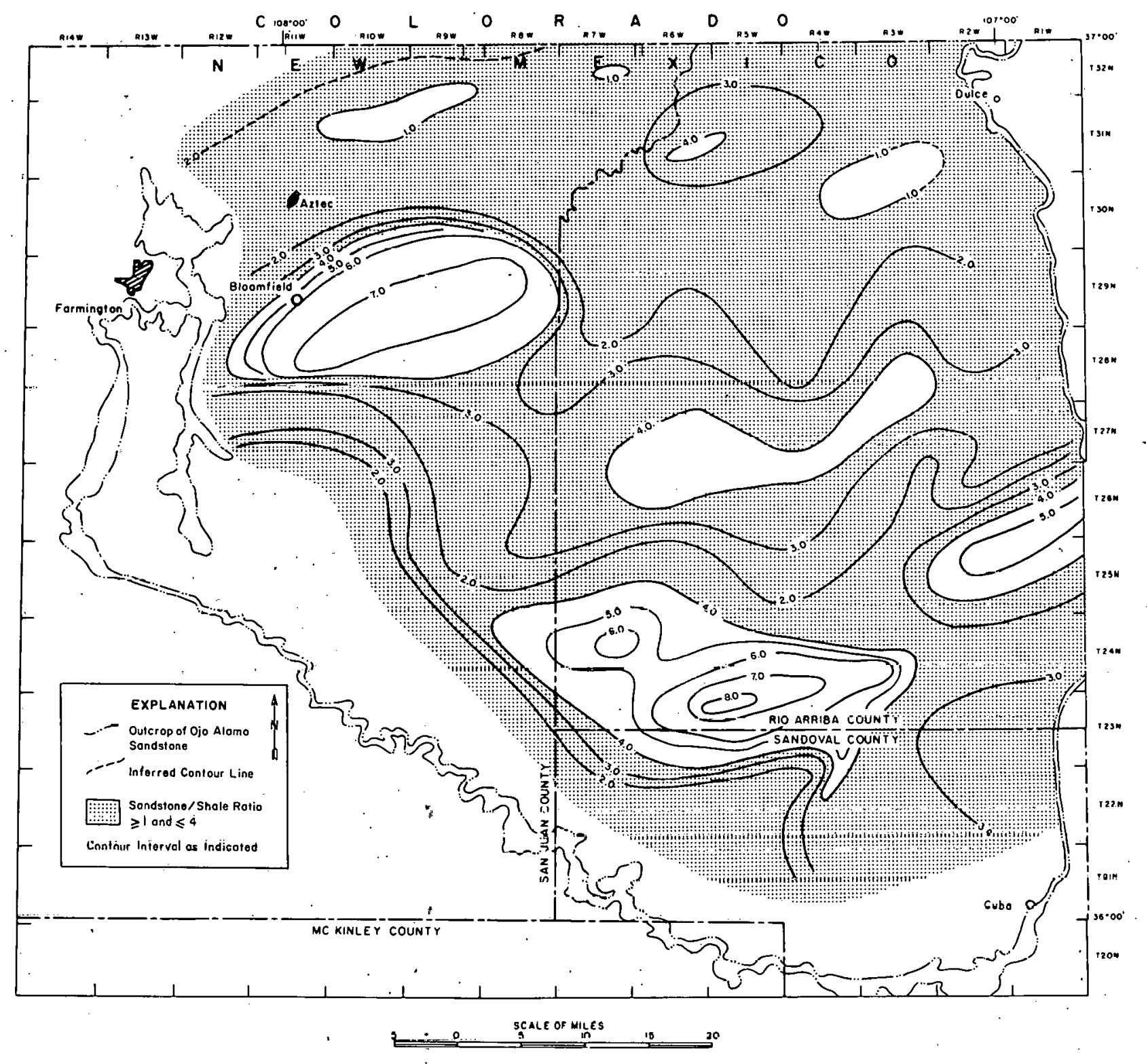

l'iguite 8. Sandstune-to-shale ratios with favorable subsurface trends, Ojo Alamo Sandstone. 




Figure 9. Total sandstone isopach, Nacimiento Formation. 


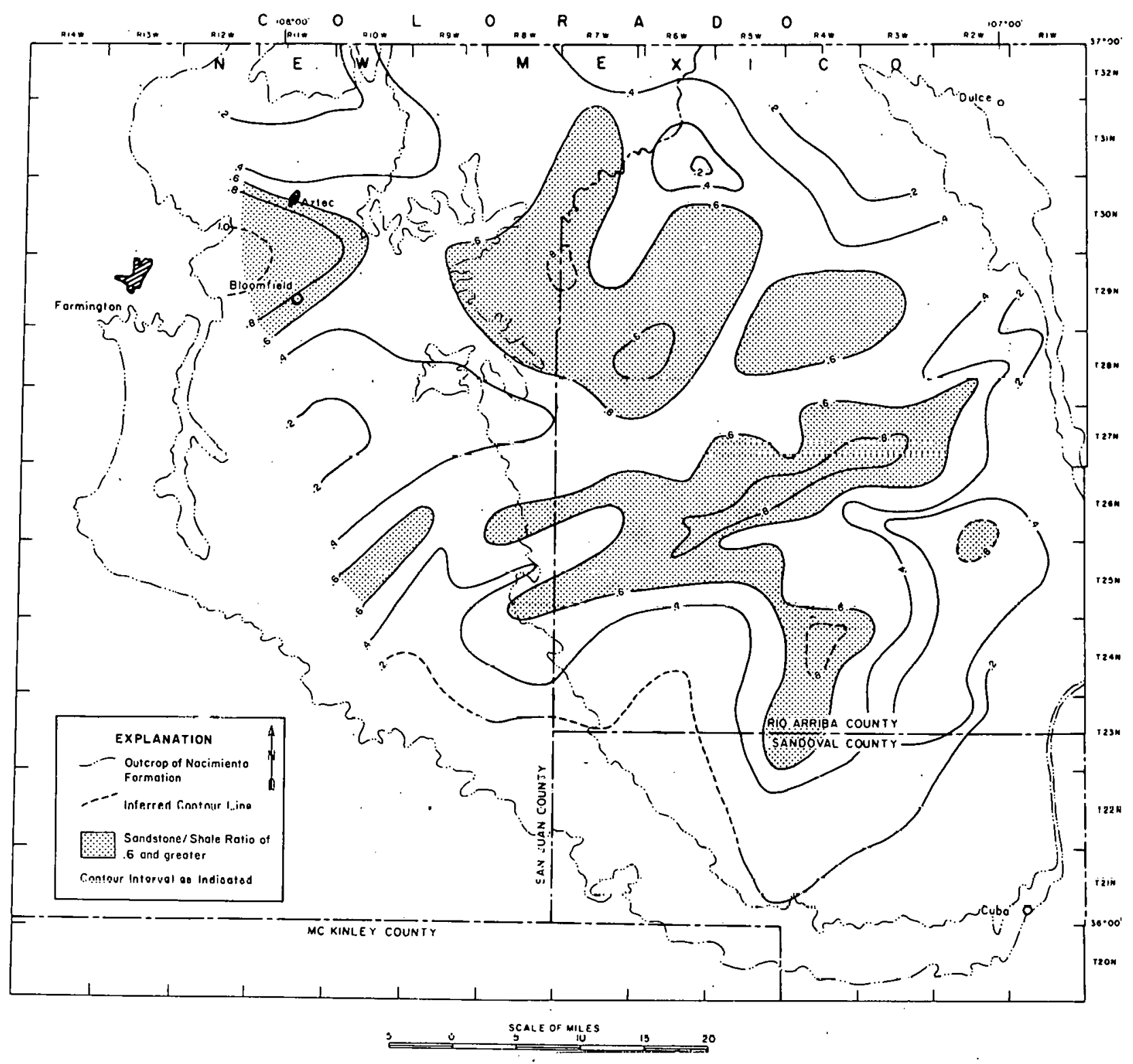

Figure 10. Sandstone-to-shale ratios with favorable subsurface trunde, Nac1micnto liormation. 


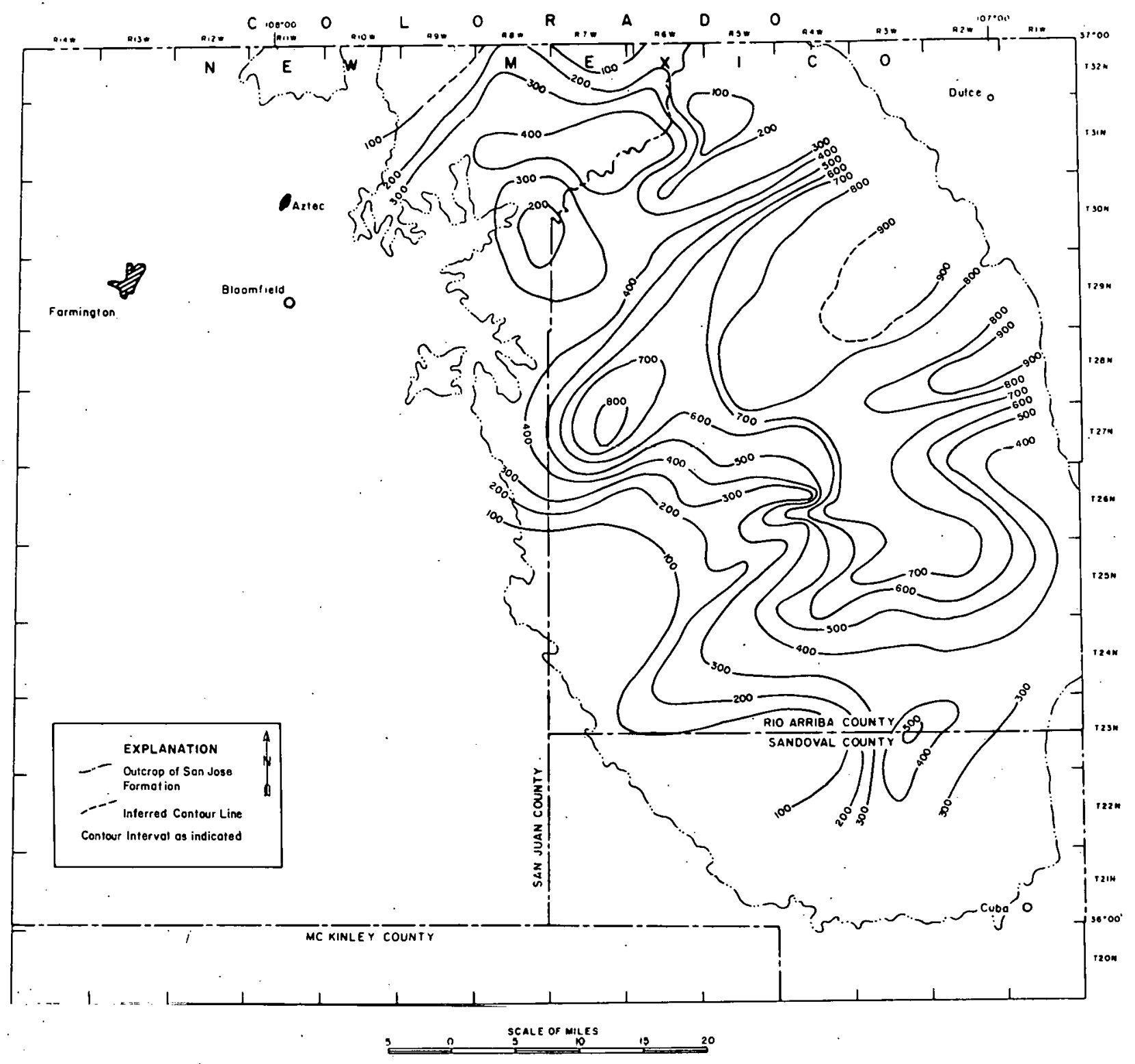

Figure 11. Total sandstone isopach, San Jose Formation. 




H'igure 1.2. Sandstone-to-shale ratios with favorable subsurface trends, San Jose Formation. 
TABLE 1. URANIUM OCCURRENCES IN TERTIARY ROCKS, SAN JUAN BASIN, NEW MEXICO.

\begin{tabular}{|c|c|c|c|c|}
\hline Name & $\begin{array}{l}\text { Location } \\
\text { Number } \\
\text { (Fig. 2) }\end{array}$ & $\begin{array}{l}\text { Host } \\
\text { Formation }\end{array}$ & $\begin{array}{c}\text { Reported Percent } \\
\mathrm{U}_{3} \mathrm{O}_{8} \\
\text { (as indicated) }\end{array}$ & Reference \\
\hline Houston prospect & 1 & Ojo Alamo Sandstone & 0.05 & $\begin{array}{l}\text { Matthewson, D. E., 1953, } \\
\text { PRR ED:R-244* }\end{array}$ \\
\hline Kimbeto Trading Post & 2 & Ojo Alamo Sandstone & $0.002-0.12$ & $\begin{array}{l}\text { Chenoweth, W. L., 1955, } \\
\text { PRR ED:R-502* }\end{array}$ \\
\hline Airborne anoma1y-17. & 3 & Ojo Alamo Sandstone & 0.02 & $\begin{array}{l}\text { Brown, H. G., and Easton, } \\
\text { W., 1954, PRR ED:R-1465* }\end{array}$ \\
\hline Chilton prospect & 4 & San Jose Formation & $0.02 \% \mathrm{eU}_{3} \mathrm{O}_{8}$ & $\begin{array}{l}\text { Rock, R. L., } 1954 \\
\quad \text { PRR ED:R-271* }\end{array}$ \\
\hline Lone Star claim & 5 & San Jose Formation & $0.01 \% \mathrm{eU}_{3} \mathrm{O}_{8}$ & $\begin{array}{l}\text { Chenoweth, W. L., 1955, } \\
\text { PRR ED:R-501* }\end{array}$ \\
\hline Princess claims & 6 & San Jose Formation & 0.01 & $\begin{array}{l}\text { Chenoweth, W. L., and } \\
\text { Kittleman, L. R., 1956, } \\
\text { PRR ED:R-622* }\end{array}$ \\
\hline Carbon and Log claims & 7 & $\begin{array}{c}\text { San Jose Formation } \\
\vdots\end{array}$ & 0.2 & $\begin{array}{l}\text { Chenoweth, W. L., and } \\
\text { Kittleman, L. R., } 1956 \text {, } \\
\text { PRR ED:R-619* }\end{array}$ \\
\hline Coy claims & 8 & San Jose Formation & 0.04 & $\begin{array}{l}\text { Chenoweth, W. L., and } \\
\text { Kittleman, L. R., 1956, } \\
\text { PRR ED:R-602* }\end{array}$ \\
\hline State lease sec. 16 & 9 & San Jose Formation & 0.12 & $\begin{array}{l}\text { Brown, H. G., } 1954 \\
\text { ED:R-492* }\end{array}$ \\
\hline Highway 44 anoamly & 10 & San Jose Formation & 0.002 & $\begin{array}{c}\text { Bachman, G. O., and others, } \\
1952\end{array}$ \\
\hline Cuba Mesa anomaly & 11 & $\begin{array}{l}\text { San Jose } \\
\quad \text { (Nacimiento?) }\end{array}$ & 0.003 & $\begin{array}{c}\text { Bachman, G. O., and others, } \\
1952\end{array}$ \\
\hline
\end{tabular}

¿PRR - U.S. Atomic Energy Comm., Preliminary Reconnaissance Report, open-filed. 


\section{SUBSURFACE RADIOMETRIC ANOMALIES}

Subsurface gamma-ray logs of the Tertiary section in the San Juan Basin show weak anomalies (Fig. 6). The anomalies, however, are widespread and sometimes represent intervals greater than $50 \mathrm{ft}$.

\section{FAVORABILITY CRITERIA PRESENT}

Source of Uranium

Several possible uraniferous source areas of high to moderate relief bounded the San Juan Basin in Tertiary time (Fig. 13). These areas contributed granitic, metamorphic, volcanic, and sedimentary detritus to the basin. Urantum may also have been contributed from tuffaceous detritms emanating from extensive Incal volcanism (Bandelier Tuff), Powell (1973) Ammistialed lliab the dilrection of ojo Alamo sediment transport was mainly toward the southeast, which indicates that the sediment source was primarily in the region of the present west flank of the San Juan Mountains. An eastward decrease in pebble size supports this interpretation (Fassett and Hinds, 1971). Precambrian granitic rocks and Paleozoic and Mesozoic sedimentary rocks were probably exposed in that general area during Paleocene time. Contrary evidence (Dane, 1932; Baltz, 1967), however, favors a source northeast of the basin, possibly in the Brazos uplift area, thus increasing the likelihood that more than one provenance contributed sediments to the Ojo Alamo.

During late Paleocene time, source areas in the north, east, and south apparently began to supply volcanic and orogenic debris to the basin. According to Baltz (1967), the coarser sandstone facies of the Nacimiento Formation appears to be an extensive apron of sediment derived from rising highlands to the north (San Juan dome) and northeast (San Luis and Sangre de Cristo uplifts) of the basin. 'l'he southern shaly facies may represent the distal edges of the apron, but probably consists mainly of reworked Cretaceous sediments from the Chaco slope and possibly from the Four Corners platform (Fig. 13).

The San Jose Formation was probably deposited by a major westward-flowing drainage system, which may have originated in the San Luis and Sangre de Cristo uplifts (Baltz, 196\%; McDonald, 1972). Local sources, prohab1y the Nacimiento and Brazos Mountains, provided considerable amounts of sediment eroded mainly from exposed Cretaceous and older sedimentary rocks. The shale facies in the San Jose was probably derived from these adjacent highlands. The coarse to conglomeratic sandstones consist mainly of first-cycle detritus of predominantly Precambrian granitic, metamorphic, and volcanic rocks. These were derived mainly from the San Luis and Sangre de Cristo uplifts and, to a lesser extent, from the San Juan dome area (Baltz, 1967; McDonald, 1972).

\section{Paleoenvironments}

The Tertiary formations of the San Juan Basin were all deposited in similar continental environments. Thick conglomeratic sandstone facies with 


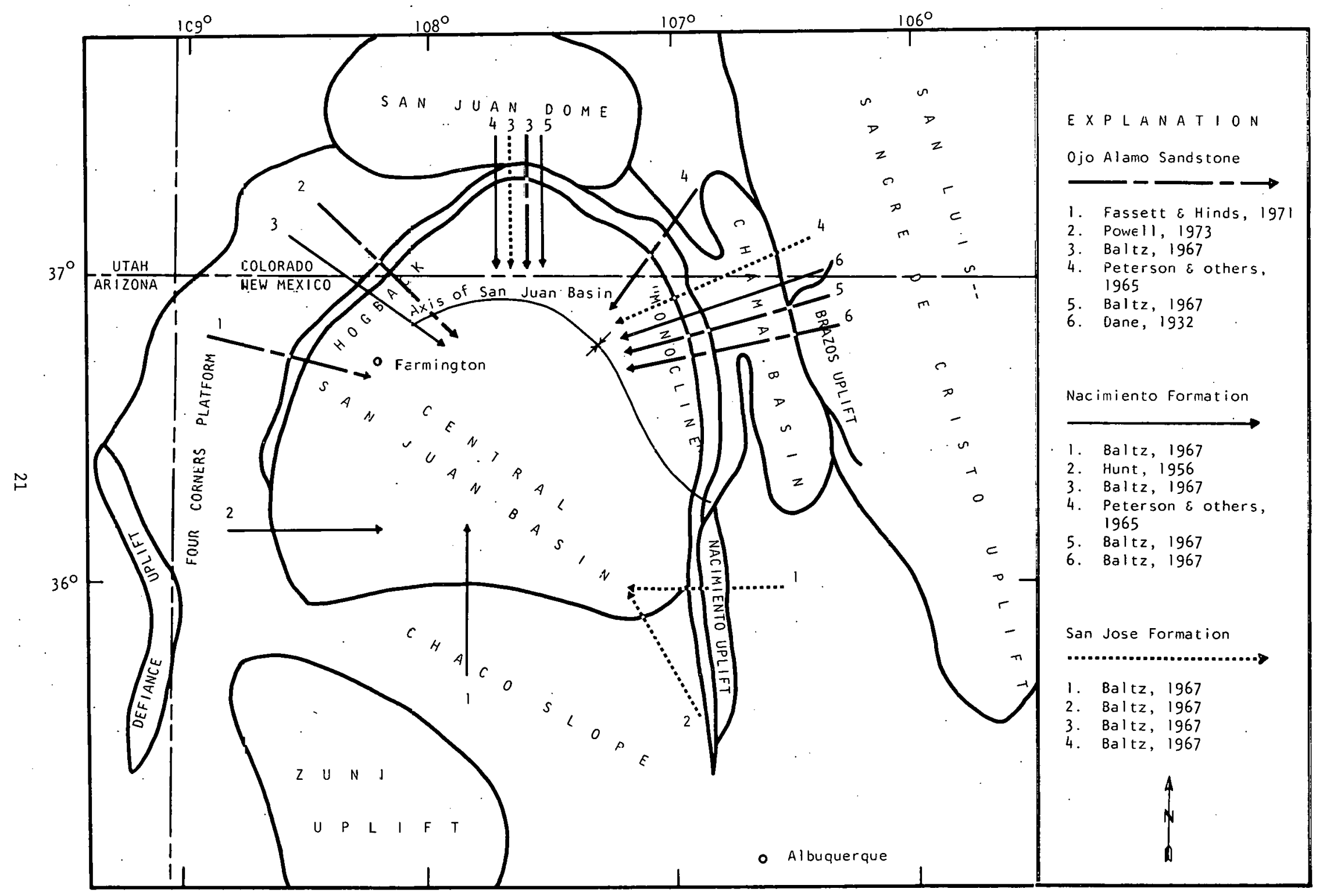

Figure 13. Early Tertiary paleogeographic map showing possible sediment source areas. 
interfingering shales in the 0 jo Alamo, Nacimiento, and San Jose are interpreted as complex channel and flood-plain systems. Extensive mudstone and siltstone, interbedded with lignite and carbonaceous shales, are well-developed in the Nacimiento and the basal San Jose, and attest to widespread paludal conditions during early Tertiary time. Deep intraformational scouring is present at the basal unconformities and at formational interfaces (P1. 1, Fig. 3).

\section{$\underline{\text { Reductants }}$}

Carbonaceous material, including logs, is locally present in outcrops of the Ojo Alamo Sandstone and Nacimiento and San Jose Formations. Petrified logs are also common in these units. Thin lignitic beds associated with claystone and finely divided pyrite are in the basal San Jose and parts of the Nacimicnto: Eulfidcs, oxides, sulfates, and traces of calluniles form halos around many carbonized logs.

\section{Host Rocks}

The Ojo Alamo Sandstone is quartzose, feldspathic, and conglomeratic. It is as much as $240 \mathrm{ft}$ thick, but thins and wedges out to the north near the New Mexico-Colorado border. The 0jo Alamo has high sandstone-to-shale ratios because of a paucity of shale interbeds. Carbonaceous debris is found locally near its base, the site of deep channel scouring.

The Nacimiento Formation contains numerous thick, feldspathic sandstone units, which are reflected by net sand thicknesses of 160 to $400 \mathrm{ft}$ and relatively low sandstone-to-shale ratios. The sandstone units have claystone, siltstone, mudstone, and carbonaceous shale interbeds.

I'he basal tacies of the San Josc (Cuba Mesa Member) is an arkosic, conglomeratic sandstone intercalated with thin beds of variegated shale and siltstone. Carbonaceous debris is abundant locally. The average thickness of the basal facies is $300 \mathrm{ft}$, and sandstone-to-shale ratios generally exceed 1.0 .

\section{RFSIITTS}

\section{GENERAL}

A series of subsurface lithofacies maps which depict general trends of early Tertiary paleostream complexes in the central San Juan Basin were compiled. Maps showing net (total) sandstone thicknesses and sandstone-toshale ratios reflect the distribution of sandstone and mudstone and, therefore, aid in differentiating channel and flood-plain depositional environments. Channel facies, which may be favorable for uranium deposition, are delineated for each of the Tertiary formations in the basin (Figs, 7-12). The general structure of the basin is represented by a structure contour map of the base of the Ojo Alamo Sandstone (Fig. 5) and by a set of stratigraphic cross sections ( $P 1$ s. $.1-4$ ). 
Surface radiometric traverses and examination of subsurface gamma-ray logs yielded results of questionable validity. These data were used to refine the favorability of the Tertiary units studied only in conjunction with other field and subsurface information.

Field examination of known uranium occurrences in the Tertiary section of the basin provided some information on lithologic character of possible significance in the favorability assessment. The radioactive zones, however, were weak, small, and widely scattered.

SUBSURFACE INVESTIGATIONS

\section{Lithofacies Mapping}

Channcl sandstone complexes that may include favorable uranium host rocks in parts of each formation were studied. Sandstone depositional trends generally are represented by thicker sandstone sections and sandstone-to-shale ratios of approximately 1 to 4 .

The net (total) sandstone and sandstone-to-shale ratio maps (Figs. 7-12) indicate dominant sandstone trends that reflect early Tertiary paleodrainage in the central San Juan Basin. Subsurface cross sections (P1s. 1-4) also indicate deep paleochannels that conform well with paleodrainage trends (Fig. 13).

Lithofacies maps of the 0jo Alamo Sandstone (Figs. 7, 8), denote a major sandstone complex that trends generally east-southeast. This trend generally coincides with Ojo Alamo paleochannel directions reported by Powell (1973). Secondary sandstone trends, probably not distributaries of the major system, suggest other, minor early Paleocene dxainage patterns.

A thick sandstone interval, well developed in both the Nacimiento and San Jose Formations, trends generally west and southwest (Figs. 9-12), and reflects a pronounced change in the basin's paleodrainage. The spatial coincidence of major sandstone complexes in both the San Jose and Nacimiento suggests that a major fluvial system, originating to the northeast, was dominant during the late Paleocene and early Eocene epochs. Subsidiary sandstone trends in both formations reflect probable tributaries to the main fluvial systems and possibly to other minor paleostream systems.

Data from Gamma-Ray Logs

Subsurface radioactivity anomalies in the Tertiary section are weak but widespread. Some anomalies persist throughout thickness intervals greater than $50 \mathrm{ft}$ (Fig. 6). The distribution pattern of the anomalies closely follows the axial trace of the basin (Fig. 5). 


\section{SURFACE INVESTIGATIONS}

\section{Radiometric Survey}

Carborne radiometric traverses with a Mt. Sopris SC-131 Scintillometer were made in the vicinity of reported uranium occurrences and atong Canyon Largo, a feature that cuts diagonally across most of the central basin. The traverses were conducted in a general field reconnaissance of the basin. No radioactivity greater than $1.5 \mathrm{X}$ background was encountered.

\section{Known Uranium Occurrences}

Previously reported uranium occurrences (Fig. 2: Table 1) in Tertiary formations in the San Juan Basin were identified during this study as weak lócal anomalies. Radioactivity is restricted mainly to black shales or carbonaceous debris associated with permeable sandetone strata. No other lithologic or outstanding field characteristics were common to the various uranium occurrences.

\section{CONCLUSIONS}

No evidence of high-level radioactivity was found in the Tertiary rocks of the central San Juan Basin; however, possible uranium host beds abound in the Tertiary section. The formations all consist predominantly of fluvial and flood-plain sediments deposited in high- to low-energy environments. Rock compositions suggest a uraniferous provenance, a pnssihle reductant is present as carbonaceous debris, and the fluvial beds are differentially permeable,

The ojo Alamo Sandotone in the study ares lias fiew shale Interbeds and abundant pebble conglomerates and varies in thickness. Sandstone-to-shale ratios and porosity are generally too high to be favorable. Locally, the more favorable zones are at the base of the unit near the Cretaceous-Tertiary unconformity, where channel scouring may be present.

The Nacimiento Formation in the central basin contains numerous thick, feldspathic sandstone units with abundant carbonaceous shale interbeds: Sandstone-to-shale ratios on the Nacimiento are favorable in the northern part of the basin, but are unfavorable in the southern part of the basin.

The basal facies of the San Jose Formation is an arkosic sandstone intercalated with shale and siltstone. It has favorable sandstone-to-shale ratios (between 1 and 4) and contains carbonaceous debris. The upper San Jose has been deeply eroded, and it is probable that, in the absence of vanadium to fix uranium, any uranium deposits in the breached section would have been leached away by oxidizing ground waters. A favorable area for uranium deposition is depicted in Figure 14. 




Figure 14. Uranium favorability map. 


\section{BIBLIOGRAPHY}

Bachman, G. O., Baltz, E. H., and O'Sullivan, R. B., 1952, Reconnaissance for uranium-bearing carbonaceous rocks in New Mexico: U.S. Geol. Survey, TEI-198, Open-File Rept., 20 p.

Baltz, E. H., 1967, Stratigraphy and regional tectonic implications of part of Upper Cretaceous and Tertiary rocks, east-central San Juan Basin, New Mexico: U.S. Geol. Survey Prof. Paper 552, 101 p.

Baltz, E. H., Ash, S. R., and Anderson, R. Y., 1966, History of nomenclature stratigraphy of rocks adjacent to the Cretaceous-Tertiary boundary, western San Juan Basin, New Mexico: U.S. Geol. Survcy Prof. Paper 524-D, 23 p.

Baltz, E. H., and West, S. R., 1967, Ground-water resources of the southern part of the Jicarilla Apache Indian Reservation and adjacent areas, New Mexico: U.S. Geo1. Survey Water-Supply Paper 1576-H, 89 p.

Brimha11, R. M., 1973, Ground-water hydrology of Tertiary rocks of the San Juan Basin, New Mexico, in Cretaceous and Tertiary rocks of the southern Colorado Plateau: Four Corners Geol. Soc. Cretaceous and Tertiary Mem., p. 197-207.

Chenoweth, W. L., 1957, A reconnaissance for uranium in the uppermost Cretaceous and early Tertiary rocks of the eastern San Juan Basin, New Mexico: U.S. Atomic Energy Comm. RME-97 (pt. 2), Open-File Rept., $18 \mathrm{p}$.

Chenoweth, W. L., and Stehle, F. T., 1957, Reconnaissance for uranium in parts of the San Juan Basin, New Mexico and Coloradn: TI.S. Atomic Énergy Comm. TM 114, Open-File Rept., 19 p.

Danc, C. H., 1932, Notes on the Puerco and Torrejon Formations, San Juan Basin, New Mexico: Washington Acad. Sci. Jour., 22, p. 406-411.

Fassett, J. E., and Hinds, J. S., 1971, Geology and fuel resources of the Fruitland Formation and Kirtland Shale of the San Juan Basin, New Mexico and Colorado: U.S. Geol. Survey Prof. Paper 676, 75 p.

Hilpert, L. S., 1969, Uranium resources of northwestern New Mexico: U.S. Geol. Survey Prof. Paper 603, 166 p.

Hunt, C. B., 1956, Cenozoic geology of the Colorado Plateau: U.S. Geo1. Survey Prof. Paper 279, 99 p.

Kelley, V. C., 1950, Regional structure of the San Juan Basin, in New Mexico Geol. Society Guidebuok, 1st Fleld Conference, San Juan Basin, New Mexico and Colorado: p. 101-108. 


\section{BIBLIOGRAPHY (continued)}

Kelley, V. C., 1955, Regional tectonics of the Colorado Plateau and relationship to the origin and distribution of uranium: New Mexico Univ. Pubs. Geology, no. 5, 120 p.

McDonald, R. E., 1972, Eocene and Paleocene rocks of the southern and central basins, in Geologic atlas of the Rocky Mountain region: Rocky Mtn. Assoc. Geologists, p. 243-257.

Peterson, J. A., Loleit, A. J., Spencer, C. W., and Ullrich, R. A., 1965, Sedimentary history and economic geology of San Juan Basin: Am. Assoc. Petroleum Geologists, v. 49, no. 11, p. 2076-2119.

Powe11, J. S., 1973, Paleontology and sedimentation models of the Kimbeto member of the 0jo Alamo Sandstone, in Cretaceous and Tertiary rocks of the southern Colorado Plateau: Four Corners Geol. Soc. Cretaceous and Tertiary Mem., p. 111-122.

Simpson, G. G., 1948, The Eocene of the San Juan Basin, New Mexico: Am. Jour. Sci., v. 246, pt. 2, p. 363-385. 


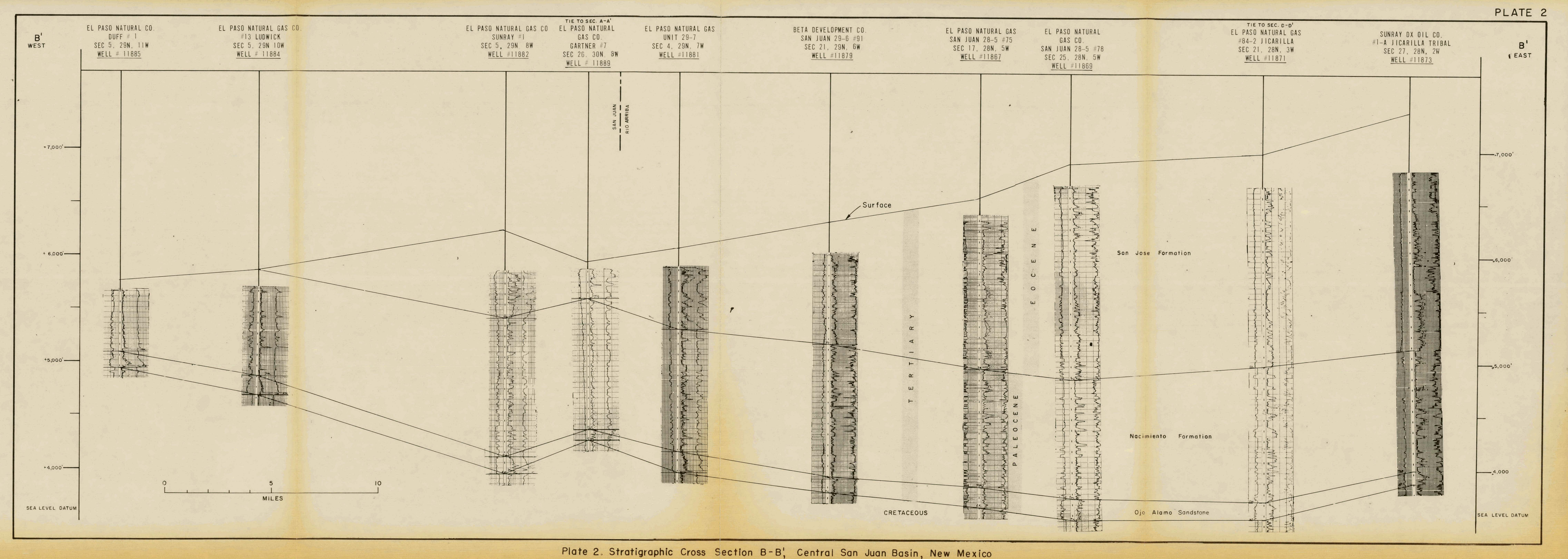







